\title{
Victor Hugo, Charles-Augustin Sainte-Beuve, Correspondance
}

\section{Lise Sabourin}

\section{Q OpenEdition}

10 Journals

\section{Édition électronique}

URL : https://journals.openedition.org/studifrancesi/46094

DOI : $10.4000 /$ studifrancesi.46094

ISSN : 2421-5856

\section{Éditeur}

Rosenberg \& Sellier

\section{Édition imprimée}

Date de publication : 1 octobre 2007

Pagination : 465-466

ISSN : 0039-2944

\section{Référence électronique}

Lise Sabourin, «Victor Hugo, Charles-Augustin Sainte-Beuve, Correspondance », Studi Francesi [En ligne], 152 (LI | II) | 2007, mis en ligne le 30 novembre 2015, consulté le 24 novembre 2021. URL: http://journals.openedition.org/studifrancesi/46094; DOI : https://doi.org/10.4000/studifrancesi. 46094

Ce document a été généré automatiquement le 24 novembre 2021.

\section{(c)}

Studi Francesi è distribuita con Licenza Creative Commons Attribuzione - Non commerciale - Non opere derivate 4.0 Internazionale. 


\title{
Victor Hugo, Charles-Augustin Sainte-Beuve, Correspondance
}

\author{
Lise Sabourin
}

\section{RÉFÉRENCE}

VICTOR HUGO, CHARLES-AUGUSTIN SAINTE-BEUVE, Correspondance, édition établie, présentée et annotée par Anthony GLINOER, Paris, Honoré Champion, 2004, pp. 238.

1 On connaît les difficultés de la relation privilégiée de panégyriste à mentor, de chef légendaire à émule déçu, les liens d'amitié puis d'hostilité qu'entretiennent Hugo et Sainte-Beuve. Le regroupement des cent vingt lettres qu'ils ont échangées de 1827 à 1845 permet bien de suivre «la chronique voilée de cette fraternité déchue» (p. 15).

2 La préface d'Anthony Glinoer (pp. 15-34) comporte des notes assez mal présentées et se borne à retracer l'évolution de la relation biographique des deux auteurs, sans ajouter une analyse littéraire de leur lien épistolaire. Mais, muni d'une liste des éditions originales et des publications antérieures, d'un index nominum, d'une bibliographie sélective, ce volume, même s'il n'apporte qu'une demi-douzaine d'inédits, permet désormais de rassembler la collection croisée de lettres par ailleurs disséminées dans leurs immenses correspondances générales. 